\title{
PENGARUH PEMBERIAN PUPUK ORGANIK CAIR URIN SAPI TERHADAP PERTUMBUHAN BIBIT PEPAYA MERAH DELIMA ( CARICA PAPAYA L)
}

\author{
Muhammad Pauzi ${ }^{1}$, Wahyudi ${ }^{2}$, Seprido ${ }^{2}$ \\ ${ }^{1}$ Mahasiswa Program Studi Agroteknologi Fakultas Pertanian UNIKS \\ ${ }^{2}$ Dosen Program Studi Agroteknologi Fakultas Pertanian UNIKS \\ Email: fauzy.mfz@gmail.com
}

\begin{abstract}
This study aims to determine the effect of various treatments of liquid organic fertilizer cow urine on the growth of red pomegranate papaya seedlings (Carica papaya L). This study used a non-factorial randomized block design (RAK), namely liquid organic cow urine (S) from 5 treatment levels: SO (without giving cow urine POC), S1 (giving cow urine POC with 40\% concentration), S2 (giving cow urine POC). 50\% concentration of cows), S3 (gives $60 \%$ concentration of cow urine POC), S4 (70\% concentration of cow urine POC). Observational data from each treatment were analyzed statistically, and if they were significantly different, it would be continued with the Follow-Up Test of Honest Significant Difference (BNJ) at the $5 \%$ level. Based on the research that has been done, it can be concluded that the application of various treatments of liquid organic fertilizer cow urine has a significant effect on the observation parameters of seedling height, stem diameter, and number of leaves. with the best treatment in S3 (giving POC cow urine with a concentration of 60\%) with a seedling height of red and pomegranate papaya $(25.04 \mathrm{~cm})$, stem diameter $(10.73 \mathrm{~mm})$, number of leaves (9.66 pieces).
\end{abstract}

Keywords: growth, pawpaw, cow urine

\begin{abstract}
Abstrak
Penelitian ini bertujuan untuk mengetahui pengaruh berbagai perlakuan pupuk organik cair urin sapi terhadap pertumbuhan bibit pepaya merah delima ( Carica papaya L). Penelitian ini menggunakan Rancangan Acak Kelompok (RAK) Non Faktorial yaitu pupuk organik cair urin sapi (S) dari 5 taraf perlakua:S0 (tanpa pemberian POC urin sapil), S1 (pemberian POC urin sapi konsentrasi 40\%), S2 (pemberian POC urin sapi konsentrasi 50\%), S3 (pemberian POC urin sapi konsentrasi 60\%), S4 (pemberian POC urin sapi konsentrasi 70\%). Data hasil pengamatan dari masing-masing perlakuan dianalisis secara statistik, dan apabila berbeda nyata akan dilanjutkan dengan Uji Lanjut Beda Nyata Jujur (BNJ) pada taraf $5 \%$. Berdasarkan penelitian yang telah dilakukan dapat disimpulkan bahwa pemberian berbagai perlakuan pupuk organik cair urin sapi memberikan pengaruh yang nyata terhadap parameter pengamatan tinggi bibit, diameter batang, dan jumlah daun. dengan perlakuan terbaik pada S3 (pemberian POC urin sapi konsentrasi 60\%) dengan tinggi bibit pepaya merah delima $(25,04 \mathrm{~cm})$, diameter batang $(10,73 \mathrm{~mm})$, jumlah daun $(9,66$ helai $)$.
\end{abstract}

Kata kunci: pertumbuhan, pepaya, urin sapi

\section{Pendahuluan}

\begin{tabular}{llrr}
\multicolumn{2}{c}{ Pepaya } & (Carica papaya & L.) \\
merupakan salah satu komoditas buah & suan \\
tropika & yang & berpotensi & untuk
\end{tabular}

dikembangkan. Menurut Suketi (2011) buah pepaya sangat potensial untuk dijadikan bahan pangan pelengkap sebagai buah segar karena harga yang relatif murah, mudah 
Pupuk POC Urin sapi adalah pupuk didapat dan mengandung vitamin A, vitamin $\mathrm{C}$ dan mineral terutama kalsium.

Pepaya merah delima merupakan salah satu varietas unggul buah tropika hasil penelitian dari Badan Litbang Pertanian. Rasanya sangat manis, legit, dan tidak beraroma, sehingga sebagian masyarakat di Jambi dan Sumatera Barat menyebutnya dengan pepaya madu. Selain itu pepaya merah delima mempunyai ukuran buah sedang, rongga buah berbentuk bintang bersudut lima, warna daging buah merah, dan tekstur daging buahnya kenyal (Budiyanti dan Noflindawati.2014).

Tanaman pepaya sudah di

budidayakan secara intensif di Kabupaten Kuantan Singingi. Berdasarkan data Badan Pusat Statistik (2021), menunjukan bahwa produksi pepaya di Kabupaten Kuantan Singingi masih berfluktuasi setiap tahunnya. Produksi pepaya pada tahun 2018 sampai tahun 2020 yaitu sebesar 492,3 ton pada tahun 2018, 345 ton pada tahun 2019 dan 360 ton pada tahun 2020. Namun secara potensi produksi pepaya di Kabupaten Kuantan Singingi masih rendah. Sementara untuk potensi produksi pepaya per musim buah ( 4 bulan) yaitu $86-100$ ton/ ha. Hal in juga disebabkan oleh penggunaan bibit yang kurang bermutu. Menurut Tim Inisiator Revolusi Orange (2013) untuk meningkatkan kualitas dan kuantitas pepaya diperlukan perbaikan teknik budi daya. Salah satu tahap penting dalam budi daya tersebut adalah teknologi produksi bibit guna menghasilkan bibit pepaya berkualitas baik.

Salah satu unsur penting dalam teknologi pembibitan adalah ketersediaan unsur hara di pembibitan. Kondisi tanah di Riau terutama di Kabupaten Kuantan Singingi yang di dominasi tanah mineral masam dengan jenis tanah Podzolik Merah Kuning (PMK) atau tanah ultisol (Dinas Tanaman Pangan Kuantan Singingi. 2015). Tanah podzolik merah kuning identik dengan tanah yang kurang subur, dicirikan dengan warna cerah bearti kekurangan bahan organik, serta memiliki kandungan hara yang rendah (Hakim, 2006). Kondisi tanah seperti ini kurang baik digunakan untuk pembibitan pepaya merah delima. Pembibitan pepaya merah delima hendaknya menggunakan tanah yang subur agar pertumbuhan baik, untuk itu perlu dilakukan pemberian pupuk yang sesuai dengan dosis yang tepat sehingga pertumbuhan pertumbuhan pepaya dapat meningkat. sumber unsur hara seperti pupuk organik cair urin sapi. yang berasal dari urin sapi yang telah difermentasikan, dimana ketersediaan bahan baku pembuatan pupuk ini di Kabupaten Kuantan Singingi sangat mudah di dapat, karena berdasarkan data laporan Dinas Peternakan Kabupaten Kuantan Singingi (2016) data populasi sapi yang ada di Kabupaten Kuantan Singingi berfluktuasi setiap tahunnya, data populasi sapi tahun 2013 yaitu 26.215, mengalami penurunan pada tahun 2014 yaitu 22.075 ekor, dan mengalami peningkatan tahun 2015 yaitu 23. 524 ekor. Hal ini memberikan potensi yang luar biasa sebagai sumber bahan pembuatan POC Urin sapi. Selain mudah di dapatkan POC Urin sapi juga dapat memperbaiki sifat fisik, kimia dan biologi tanah.

Menurut Affandi (2008), urin sapi bermanfaat untuk memperbaiki struktur kandungan organik tanah selain itu menghasilkan produk pertania yang aman bagi kesehatan, meningkatkan kesuburan tanah, memperbaiki kondisi biologi tanah dan kimia tanah sehingga unsur hara dalam tanah yang bisa di manfaatkan tanaman secara optimal.

Menurut Isrianto (2017), jenis kandungan hara pada pupuk organik cair urin sapi urin sapi yaitu : 1,29\% Nitrogen, $2,03 \%$ Fosfor dan 1,92\% Kalium. Selain itu urin sapi juga mengandung zat perangsang tumbuh yang dapat digunakan sebagai pengatur tumbuh diantaranya IAA. Lebih lanjut dijelaskan bahwa urin sapi juga memberikan pengaruh positif terhadap pertumbuhan vegetatif tananaman. Karena baunya yang khas, urin sapi juga dapat mencegah datangnya berbagai hama tanaman, sehingga urin sapi juga dapat berfungsi sebagai pengendalian hama tananaman serangga.

Dengan kandungan yang terdapat dalam pupuk organik cair urin sapi, maka urin sapi sangat berpotensi jika digunakan sebagai pupuk dalam pembibitan tanaman pepaya. Urin sapi juga mengandung zat pengatur tumbuh alami yang dapat digunakan oleh tanaman, selain relatif lebih mudah diperoleh juga sederhana penggunaannya. Peranan zat pengatur tumbuh pada pembibitan adalah untuk memacu pertumbuhan bibitPenelitian ini bertujuan untuk mengetahui pengaruh pemberian Pupuk Organik Cair urin sapi terhadap pertumbuhan bibit pepaya merah delima( Carica papaya $\mathrm{L}$ )

\section{METODOLOGI PENELITIAN}


Penelitian ini telah dilaksanakan di Lingkungan III Sinambek Kelurahan Sungai Jering Kecamatan Kuantan Tengah Kabupaten Kuantan Singingi. Waktu penelitian telah di laksanakan pada bulan Juni sampai Agustus 2021 (lampiran 1).

Bahan yang digunakan adalah benih pepaya varietas merah delima, POC urin sapi, pupuk kandang sapi, tanah top soil, arang sekam papan merek, Polybag ukuran $15 \times 15$. Sedangkan alat yang digunakan adalah, meteran, paranet, jangka sorong, cangkul, parang, palu dan alat tulis.

Rancangan yang dipakai dalam penelitian ini adalah: Rancangan Acak Kelompok (RAK) non faktorial, yaitu pupuk POC urin sapi (S) yang terdiri dari 5 taraf perlakuan. Masing-masing perlakuan terdiri dari 3 kali ulangan. Jumlah plot yang digunakan sebanyak 15 plot, pada masing masing plot terdiri dari 4 tanaman dan 3 diantaranya dijadikan tanaman sampel. Jumlah tanaman keseluruhan 60 tanaman. Adapun perlakuannya sebagai berikut :

So : Tanpa Perlakuan ( Kontrol )

$\mathrm{S}_{1}$ : Pemberian POC Urin Sapi

Konsentrasi $40 \%$

$\mathrm{S}_{2} \quad$ : Pemberian POC Urin Sapi

Konsentrasi $50 \%$

$\mathrm{S}_{3}$ : Pemberian POC Urin Sapi

Konsentrasi $60 \%$

$\mathrm{S}_{4}:$ Pemberian POC Urin Sapi

Konsentrasi $70 \%$

Dari hasil pengamatan masing-masing

perlakuan dianalisis secara statistik dari $\mathrm{F}$ tabel 5\%, maka dilanjutkan dengan uji

lanjut beda nyata jujur (BNJ) $5 \%$.

Untuk mendapatkan kesimpulan dari hasil penelitian ,maka data di analisi secara statistic. Sesuai dengan Rancangan Acak Kelompok (RAK) Non Faktorial dengan model analisis sebagai berikut:

\section{Yij $\quad=\boldsymbol{\mu}+\mathbf{t i}+\mathbf{k j}+\varepsilon \mathbf{i j}$}

Apabila $F$ hitung lebih besar dari $F$ tabel, maka dilanjutkan dengan Uji Lanjut Beda Nyata Jujur (BNJ) pada taraf $5 \%$.

Penelitian, Pembuatan Plot, Pembuatan Naungan, Persiapan Media Tanam, Penyemaian Benih Pepaya, Pemindahan Bibit ke Dalam Polybag, Perlakuan POC Urin Sapi.

\section{HASIL DAN PEMBAHASAN}

\section{Tinggi Tanaman (cm)}

Data hasil pengamatan terhadap parameter tinggi bibit pepaya merah delima, setelah dilakukan analisis sidik ragam ( Lampiran 5), menunjukan bahwa perlakuan pemberian POC urin sapi berpengaruh nyata terhadap tinggi bibit pepaya merah delima.
Hasil uji lanjut Beda Nyata Jujur ( BNJ) pada taraf $5 \%$ dapat dilihat pada tabel 1

Tabel 1. Rerata Hasil Pengamatan Tinggi Bibit Pepaya Merah DelimaUmur 6 Minggu Setelah Tanam Dengan Pemberian POC Urin Sapi

Rerata Perlakuan ( S)

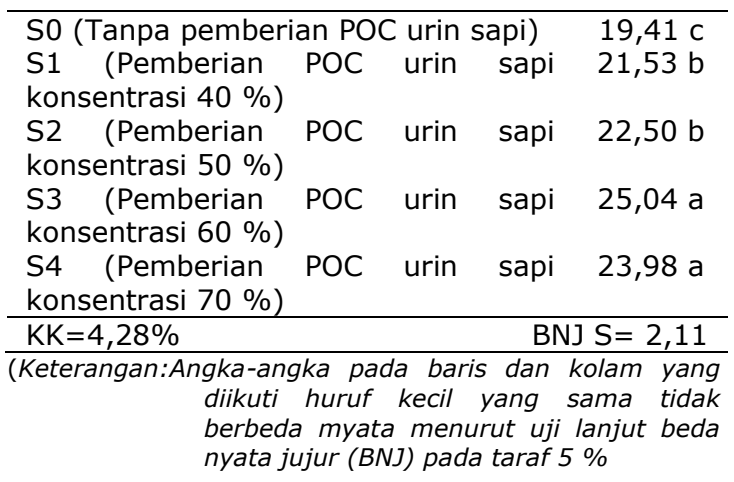

Berdasarkan tabel 4 dapat dilihat bahwa perlakuan pemberian pupuk organic cair (POC) urin sapi terhadap tinggi bibit pepaya memberikan pengaruh yang nyata. Tinggi tanaman bibit pepaya paling tinggi terdapat pada perlakuan S3 (Pemberian POC urin sapi konsentrasi $60 \%$ ) yaitu $25,04 \mathrm{~cm}$ Perlakuan S3 tidak berbeda nyata dengan perlakuan yaitu S4 (Pemberian POC urin sapi konsentrasi $70 \%)$, namun berbeda nyata dengan perlakuan S2 (Pemberian POC urin sapi konsentrasi $50 \%$ ), S1(Pemberian POC urin sapi konsentrasi $40 \%$ ) dan S0 ( Tanpa pemberian POC urin sapi). Perlakuan S0 merupakan tinggi bibit paling rendah yaitu $19,41 \mathrm{~cm}$

Pemberian POC urin sapi memberikan hasil terbaik pada perlakuan $\mathrm{S} 3$ (Pemberian POC urin sapi konsentrasi 60 \%) untuk tinggi bibit pepaya merah delima. Bibit pepaya dengan perlakuan ini menunjukan hasil yang terbaik yaitu $25,04 \mathrm{~cm}$.. Hal ini disebabkan ketersediaan unsur hara yang cukup bagi tanaman, oleh karena itu pemberian konsentrasi POC urin sapi yang sesuai mampu memenuhi kebutuhan unsur hara tanaman selain itu POC urin sapi banyak mengandung unsur hara seperti nitrogen yang berfungsi dalam pertubuhan vegetatif tanaman.

Purwati (2013), yang menyatakan bahwa fungsi pupuk organik cair adalah memberi unsur hara pada tanaman dan tanah, serta mengandung unsur hara yang lengkap yaitu unsur hara makro dan unsur hara mikro yang dapat meningkatkan 
pertumbuhan tanaman. Tingginya konsentrasi hara yang terkandung didalam POC urin sapi khususnya Nitrogen, membuat tanaman merespon dengan baik, sehingga mengalami pertumbuhan yang optimal. Berdasarkan penelitian Isrianto (2017) urin sapi yang telah difermentasi dengan EM4 (Effective Microorganisme4) mengandung : $1,29 \%$ Nitrogen. Salah satu fungsi nitrogen bagi tanaman adalah meransang pertumbuhan tanaman secara keseluruhan, khususnya batang, dan daun.

Pranata (2004), menambahkan bahwa tumbuhan memerlukan nitrogen untuk pertumbuhan terutama pada fase vegetatif yaitu pertumbuhan cabang, daun, dan batang. Nitrogen juga bermanfaat dalam proses pembentukan hijau daun atau klorofil. Klorofil sangat berguna untuk membantu proses fotosintesis sehingga pertumbuhan tanaman berjalan dengan baik.sesuai dengan pernyataan Lakitan (2001) apabila serapan $\mathrm{N}$ meningkat, maka kandungan klorofil juga meningkat sehingga fotosintesis dan fotosintat yang dihasilkan serta dialokasikan kepertumbuhan tinggi tanaman juga meningkat.

$$
\text { Selanjutnya Sutedjo (2010) }
$$

mengatakan bahwa pupuk organik cair urin sapi juga mengandung hormon yang memacu pertumbuhan tanaman. Hormon tersebut diantaranya IAA (Indol Acetic Acid) yang dikenal sebagai auksin utama pada tanaman yang mampu memacu pertumbuhan dan perkembangan bibit pepaya, sehingga dapat memberikan pengaruh yang lebih baik terhadap pertumbuhan tanaman $\mathrm{Hal}$ ini sesuai dengan pernyataan Harjadi (2009) pemberian auksin dapat memacu perpanjangan sel sehingga dapat meningkatkan pertumbuhan batang.

Hasil penelitian ini bila dibandingkan dengan penelitian Santoso (2020) yang menggunakan POC urin sapi untuk bibit pepaya varietas California diperoleh tinggi bibit 24,8 cm maka bila dibandingkan dengan hasil penelitian yaitu $25,04 \mathrm{~cm}$, lebih tinggi sebesar $0,24 \mathrm{~cm}$.

Perlakuan S4 (Pemberian POC urin sapi konsentrasi $70 \%$ ) memberikan tinggi tanaman yang lebih rendah dibandingkan dengan perlakuan S3 Pemberian POC urin sapi konsentrasi $60 \%$ ) hal ini disebabkan pemberian POC dengan konsentrasi yang tinggi menyebabkan pertumbuhan tinggi bibit pepaya menurun. Sesuai dengan pendapat Mappanganro dkk (2011)

Perlakuan S2 (Pemberian POC urin sapi konsentrasi 50 \%) dan S1 (Pemberian
POC urin sapi konsentrasi 40 \%) menghasilkan tinggi bibit yang relatif rendah dibandingkan dengan perlakuan S3(Pemberian POC urin sapi konsentrasi 60 \%) dan S4 (Pemberian POC urin sapi konsentrasi $70 \%)$, hal ini disebabkan pemberian POC dengan konsentrasi yang terlalu encer maka jumlah unsur hara yang diberikan kepada tanaman terlalu sedikit maka tanaman akan kekurangan unsur hara dibandingkan dengan perlakuan lainnya sehingga pertumbuhan tanaman pada perlakuan S2 dan S1 lebih rendah dibandingkan dengan perlakuan lainnya. Lakitan (2012), menyatakan bahwa cukupnya kebutuhan hara tanaman akan meningkatkan pertumbuhan dan sebaliknya jika kebutuhan hara tanaman kurang mengakibatkan pertumbuhan tanaman terhambat

Rerata tinggi bibit pepaya yang paling rendah terdapat pada perlakuan kontrol SO ( tanpa pemberian POC urin sapi) pemberian pupuk dengan konsentrasi yang tinggi sampai batas tertentu akan menyebabkan hasil semakin meningkat dan pada konsentrasi yang melebihi batas tertentu dapat menyebabkan hasil menjadi menurun.yaitu 19,41 cm. hal ini terjadi kerena tanaman pada perlakuan kontrol tumbuh alami tanpa adanya pemberian pupuk organik cair, Hal ini sesuai dengan pendapat Sutedjo (2008), menyatakan bahwa pertumbuhan suatu tanaman tidak akan tumbuh dengan maksimal jika kandungan unsur hara kurang dari yang dikehendaki oleh tanaman. Untuk melihat grafik pertumbuhan bibit pepaya merah delima setiap minggunya dengan perlakuan POC urin sapi dapat dilihat pada Grafik 1.

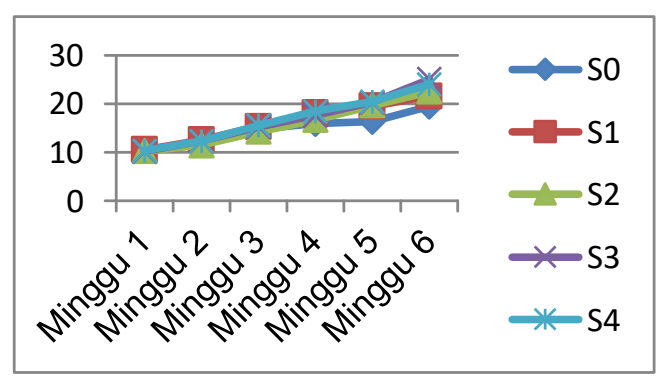

Grafik. Pertumbuhan tinggi bibit pepaya merah delima dengan pemberian POC Urin Sapi

Dari grafik 1 di atas dapat dilihat bahwa laju pertumbuhan tinggi bibit pepaya merah delima yang paling tinggi itu adalah S3 tidak berbeda nyata dengan perlakuan yaitu S4, namun berbeda nyata dengan perlakuan S0,S1 dan S2. dimana perlakuan 
S0 (kontrol) merupakan hasil yang paling rendah. Selisih tinggi bibit perlakuan S3 dengan S0 yaitu $5,63 \mathrm{~cm}$, selisih S3 dengan $\mathrm{S} 1$ yaitu $3,52 \mathrm{~cm}$, selisih $\mathrm{S} 3$ dengan $\mathrm{S} 2$ yaitu $2,55 \mathrm{~cm}$, dan selisih S3 dengan S4 yaitu 1,07 $\mathrm{cm}$.

\section{Diameter Batang ( $\mathbf{m m})$}

Data hasil pengamatan terhadap paramet diameter batang pepaya merah delima, setelah dilakukan analisis sidik ragam ( Lampiran 5), menunjukan bahwa perlakuan pemberian POC urin sapi berpengaruh nyata diameter batang bibit pepaya merah delima. Hasil uji lanjut Beda Nyata Jujur ( BNJ) pada taraf $5 \%$ dapat dilihat pada tabel 5 .

Tabel 2. Rerata Hasil Pengamatan Diameter Batang Bibit Pepaya Merah Delima Umur 6 Minggu Setelah Tanam Dengan Pemberian POC Urin Sapi

\section{Rerata}

Perlakuan ( S)

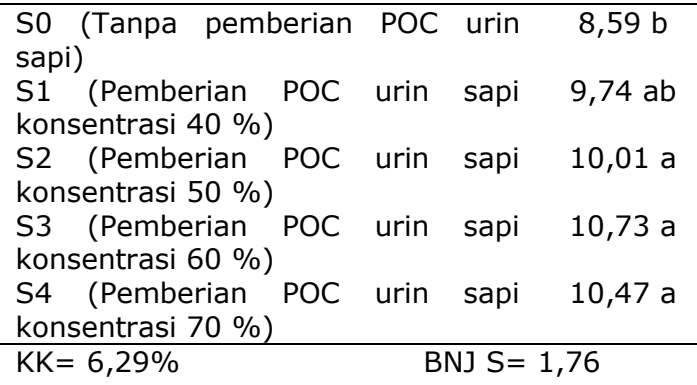

Keterangan:Angka-angka pada baris dan kolam yang diikuti huruf kecil yang sama tidak berbeda myata menurut uji lanjut beda nyata jujur ( $B N J)$ pada taraf $5 \%$

Berdasarkan tabel diatas dapat dilihat bahwa perlakuan pemberian pupuk organik cair (POC) urin sapi terhadap diameter batang bibit pepaya memberikan pengaruh yang nyata. Diameter batang bibit pepaya terbesar terdapat pada perlakuan S3(Pemberian POC urin sapi konsentrasi 60 $\%)$ yaitu 10,73 mm. Perlakuan S3 tidak berbeda nyata dengan perlakuan S4(Pemberian POC urin sapi konsentrasi 70 $\%$ ), S2(Pemberian POC urin sapi konsentrasi $50 \%$ ) dan S1(Pemberian POC urin sapi konsentrasi $40 \%$ ) namun berbeda nyata dengan perlakuan SO( Tanpa pemberian POC urin sapi). Perlakuan S0 merupakan diameter batang bibit pepaya terkecil yaitu $8,59 \mathrm{~mm}$.

Pemberian POC memberikan hasil terbaik pada perlakuan S3 Pemberian POC urin sapi konsentrasi $60 \%$ ), dimana ini merupakan POC urin sapi konsentrasi sedang sehingga jumlah hara yang diserap tanaman melalui pemberian POC urin sapi ini telah dapat diserap tanaman dengan optimum, terutama kandungan $\mathrm{N}, \mathrm{P}$ dan $\mathrm{K}$ yang terdampak terhadap diameter batang. Hal ini sesuai dengan hasil penelitian Manshuri, (2010) bahwa Efisiensi pemupukan yang optimal dapat dicapai apabila pupuk diberikan dalam jumlah yang sesuai dengan kebutuhan.

Menurut Lakitan (2007), pada pertumbuhan vegetatif tanaman organ batang, daun dan akar adalah bagian-bagian organ tanaman yang kompetitif dalam mendapatkan fotosintat. Ketersediaan unsur hara $\mathrm{N}, \mathrm{P}$ dan $\mathrm{K}$ yang tercukupi dan faktor fotosintesis lainnya dalam keadaan yang optimal dapat meningkatkan laju fotosintesis, sehingga fotosintat yang di alokasikan ke pertumbuhan diameter batang juga meningkat bila alokasi fotosintat kurang maka pertambahan diameter batang juga akan berpengaruh. Penambahan diameter batang ini disebabkan oleh pertumbuhan sekunder aktivitas kambium pembuluh yang menambah jaringan pembuluh sehingga menyebabkan pertumbuhan ke samping.

$$
\text { Selanjutnya Jumin }
$$

menjelaskan batang merupakan daerah akumulasi pertumbuhan khususnya tanaman muda, dengan adanya unsur hara dapat mendorong laju fotosintesis dalam menghasilkan fotosintat, sehingga membantu dalam pembentukan diameter batang. Pertambahan diameter batang tanaman biasanya sejalan dengan pertumbuhan tinggi tanaman, semakin tinggi suatu tanaman maka lingkar batang juga semakin lebar.

Perlakuan S2 (Pemberian POC urin sapi konsentrasi $50 \%$ ) dan S1 (Pemberian POC urin sapi konsentrasi $40 \%$ ) menghasilkan diameter batang yang relatif kecil dibandingkan dengan perlakuan S3(Pemberian POC urin sapi konsentrasi 60 $\%$ dan S4 (Pemberian POC urin sapi konsentrasi $70 \%$ ), hal ini disebabkan pemberian POC dengan konsentrasi yang terlalu encer maka jumlah unsur hara yang diberikan kepada tanaman terlalu sedikit maka tanaman akan kekurangan unsur hara sehingga pertambahan jumlah daun akan terhambat. Lingga (2002) menyatakan bahwa apabila dosis atau konsentrasi berlebihan akan menjdi racun bagi tanaman, sebaliknya bila kekurangan atau terlalu encer pertumbuhan tanaman tidak mengalami perubahan.

Rerata diameter batang bibit pepaya yang paling rendah terdapat pada perlakuan kontrol SO ( tanpa pemberian POC urin sapi) yaitu $8.59 \mathrm{~mm}$. Hal ini terjadi karena perlakuan pada SO tidak diberi pupuk organik cair sehingga pertumbuhan bibit 
tidak optimum karena kebutuhan unsur hara tanaman tidak terpenuhi. Hal ini sesuai dengan pendapat Lakitan (2012), bahwa cukupnya kebutuhan hara tanaman akan meningkatkan pertumbuhan dan sebaliknya jika kebutuhan hara tanaman kurang mengakibatkan pertumbuhan tanaman terhambat.

\section{Jumlah daun (helai)}

Data hasil pengamatan terhadap paramet diameter batang pepaya merah delima, setelah dilakukan analisis sidik ragam ( Lampiran), menunjukan bahwa perlakuan pemberian POC urin sapi berpengaruh nyata jumlah daun bibit pepaya merah delima. Hasil uji lanjut Beda Nyata Jujur ( BNJ) pada taraf $5 \%$ dapat dilihat pada tabel dibawah ini.

Tabel 3. Rerata Hasil Pengamatan Jumlah Daun Bibit Pepaya Merah Delima Umur 6 Minggu Setelah Tanam Dengan Pemberian POC Urin Sapi

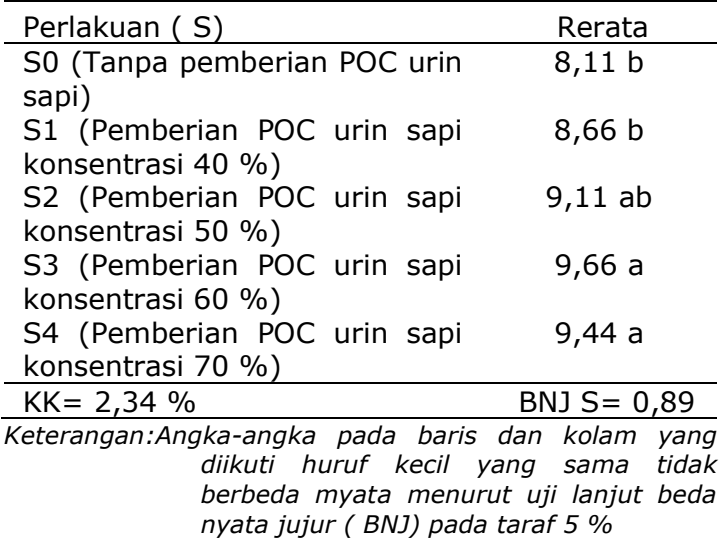

Berdasarkan Tabel 6 dapat dilihat bahwa perlakuan pemberian pupuk organik cair (POC) urin sapi terhadap jumlah daun bibit pepaya memberikan pengaruh yang nyata. Jumlah daun bibit pepaya paling bayak terdapat pada perlakuan S3 (Pemberian POC urin sapi konsentrasi $60 \%$ ) yaitu 9,66 helai daun. Perlakuan S3 tidak berbeda nyata dengan perlakuan S4(Pemberian POC urin sapi konsentrasi 70 $\%$ dan S2(Pemberian POC urin sapi konsentrasi $50 \%$ ) namun berbeda nyata dengan perlakuans1(Pemberian POC urin sapi konsentrasi 40 \%) dan SO( Tanpa pemberian POC urin sapi). Perlakuan SO merupakan jumlah daun yang paling sedikit yaitu 8,11 helai daun.

Banyaknya jumlah daun yang terdapat pada perlakuan S3 (Pemberian POC urin sapi konsentrasi $60 \%$ ), hal ini disebaban karena pemberian pupuk organik cair pada konsentrasi ini, dimana hara yang terkandung dalam pupuk organik cair telah dapat diserap dengan baik oleh bibit pepaya sehingga memberikan pengaruh yang nyata terhadap parameter jumlah daun bibit pepaya. Diantara hara yang terkandung dalam pupuk organik adalah hara yang berperan dalam pembentukan daun. Hal ini sejalan dengan penelitian Zahrah (2011) yang menyatakan bahwa pemupukan tanaman akan lebih baik bila menggunakan dosis, cara, jenis pupuk dan waktu pemberian yang tepat untuk menghasilkan pertumbuhan tanaman yang optimal.

Pemberian POC urin sapi dengan dosis yang cukup dan sesuai dapat menyumbangkan unsur hara N, P, K, Ca dan Mg. Menurut Wijaya (2008) Tanaman yang cukup mendapat suplai $\mathrm{N}$ akan membentuk daun yang memiliki helaian yang lebih luas dengan kandungan klorofil yang lebih tinggi, sehingga tanaman mampu menghasilkan karbohidrat atau asimilat yang cukup untuk menopang pertumbuhan vegetatif tanaman.

Perlakuan S2 (Pemberian POC urin sapi konsentrasi $50 \%$ ) dan S1 (Pemberian POC urin sapi konsentrasi $40 \%$ ) menghasilkan jumlah daun yang relatif rendah dibandingkan dengan perlakuan S3(Pemberian POC urin sapi konsentrasi 60 \%) dan S4 (Pemberian POC urin sapi konsentrasi $70 \%$ ), hal ini disebabkan pemberian POC dengan konsentrasi yang terlalu encer maka jumlah unsur hara yang diberikan kepada tanaman terlalu sedikit maka tanaman akan kekurangan unsur hara sehingga pertambahan jumlah daun akan terhambat. Pada penelitian Lakitan (2012), bahwa cukupnya kebutuhan hara tanaman akan meningkatkan pertumbuhan. Sebab semakin tinggi tanaman maka semakin banyak pula jumlah daun yang dihasilkan.

Rerata jumlah daun bibit pepaya yang paling sedikit terdapat pada perlakuan kontrol SO (tanpa pemberian POC urin sapi) yaitu 8.11 helai. Hal ini terjadi karena bibit tumbuh alami tanpa pemberian pupuk sehingga pertumbuhannya lebih lambat dibandingkan perlakuan lain dan jumlah daun yang dihasilkan tanaman lebih sedikit. Lingga dan Marsono (2004), menambahkan bahwa kebutuhan tanaman terhadap unsur hara, bila pemberiannya kekurangan tanaman justru akan mengalami gangguan metabolisme, bahkan menyebabkan tanaman gagal dalam pertumbuhannya.

\section{KESIMPULAN}

Berdasarkan hasil penelitian yang telah dilakukan dapat disimpulkan bahwa perlakuan pemberian Pupuk Organik Cair 
(POC) urin sapi berpengaruh nyata terhadap parameter pengamatan tinggi tanman $(25,04 \mathrm{~cm})$, diameter batang $(10,73 \mathrm{~mm})$ dan jumlah daun bibit pepaya ( 9,66 helai) dengan perlakuan terbaik S3 (Pemberian POC Urine Sapi $600 \mathrm{ml} /$ liter air).

\section{DAFTAR PUSTAKA}

[1] Affandi, 2008. Pemanfaatan Urine Sapi yang Difermentasi sebagai Nutrisi Tanaman. Andi Offset. Yogyakarta

[2] Badan Pusat Statistik Kabupaten Kuantan Singingi. 2021. Kuantan Singingi Dalam Angka

[3] Budiyanti, T., dan Noflindawati. 2014. Pepaya Merah dalam Meningkatkan Pendapatan dan Kesejahteraan Masyarakat. Jurnal Badan Penelitian Buah Tropika. 141-147.

[4] Dinas Tanaman Pangan Kabupaten Kuantan Singingi. 2015. Laporan Tahunan Dinas Tanaman Pangan Kabupaten Kuantan Singingi. Teluk Kuantan

[5] Dinas Peternakan Kabupaten Kuantan Singingi. 2016. Kuantan Singingi dalam Angka. Laporan Tahunan Dinas Peternakan Kabupaten Kuantan Singingi.

[6] Hakim, N. 2006. Pengelolaan Kesuburan Tanah Masam Dengan Teknologi Pengapuran Terpadu. Andalas University Press. Padang

[7] Harjadi, S.S. 2009. Zat Pengatur Tumbuh. Penebar Swadaya. Jakarta.

[8] Isrianto. 2017. Pengaruh Metode Pupuk Organik Cair Urin Sapi Terhadap Kadar N,P dan K. Skripsi. Jurusan Agroteknologi. Fakultas Pertanian. Universitas Islam Kuantan Singingi. Teluk Kuantan

[9] Jumin, H. B. 2009. Ekologi Tanaman Suatu Pendekatan Fisiologis. Raja Grafindo Persada. Jakarta

[10] Lakitan. B. 2012. Dasar-dasar Fisiologi Tumbuhan. Pt Rajagrafindo Perseda. Jakarta Lingga, P. 2002. Petunjuk Penggunaan Pupuk. Jakarta: Penebar Swadaya

[11] Lingga dan Marsono, 2004. Petunjuk
Penggunaan Pupuk. Redaksi Agromedia, jakarta.

[12] Manshuri, A, G. 2010. Pemupukan N, $\mathrm{P}$ dan $\mathrm{K}$ pada kedelai sesuai kebutuhan tanaman dan daya dukung lahan. Jurnal Penelitian Pertanian Tanaman

[13] Mappanganro, N., E. L. Sengin dan Baharuddin. 2011. Pertumbuhan dan Produksi Tanaman Stroberi Pada Berbagai Jenis dan Konsentrasi Pupuk Organik Cair dan Urine Sapi dengan Sistem Hidroponik Irigasi Tetes. Fakultas Pertanian Universitas Hasanuddin. Makasar.Pangan. Vol. 29(3): 171-179

[14] Pranata, A.S. 2004. Mengenal Lebih Dekat Pupuk Organik Cair, Aplikasi dan Manfaatnya. AgroMedia Pustaka. Jakarta

[15] Rosniawaty, S., R. Sudirja dan H. Afrianto. 2015. Pemanfaatan urine sapi dan urine sapi sebagai alternatif pupuk organik cair pada pembibitan kakao ( Theobroma cacao L.) Jurnal kultivasi. Volume 14 n0. 1. Maret 2015.

[16] Santoso, N. 2020. Pengaruh Urin Sapi Sebagai Pupuk Organik Cair Dengan Penambahan EM4 Terhadap Pertumbuhan Tanaman Pepaya California ( Carica papaya L) Sebagai Kajian Sumber Belajar Biologi. Skripsi.Fakultas Keguruan dan ilmu Pendidikan. Univeristas Muhammadiyah Malang. Malang

[17] Sutedjo, M.M. 2010. Pupuk dan Cara Pemupukan. Jakarta, Rineka Cipta.

[18] Sutedjo, M. 2008. Pupuk dan Cara Pemupukan. Edisi revisi. Rineka cipta. Jakarta Wijaya. K.A. 2008. Nutrisi Tanaman. Prestasi Pustaka. Jakarta

[19] Wijaya. K.A. 2008. Nutrisi Tanaman. Prestasi Pustaka. Jakarta.

[20] Zahrah, S. 2011. Respons Berbagai Varietas Kedelai (Glycine Max (L) Merril) terhadap Pemberian Pupuk NPK Organik. Fakultas Pertanian dan Program Pascasarjana Universitas Islam Riau 